\title{
Improving Cold Tolerance through In Vitro Selection for Somaclonal Variations in Seashore Paspalum
}

\author{
June Liu ${ }^{1}$, Zhimin Yang', Weiling Li, and Jingjin Yu \\ College of Agro-Grassland Science, Nanjing Agricultural University, Nanjing 210095, People's \\ Republic of China \\ Bingru Huang ${ }^{2}$ \\ Department of Plant Biology and Pathology, Rutgers University, 59 Dudley Road, New Brunswick, \\ NJ 08901
}

\begin{abstract}
AdDitional INDEX wORDs. callus, low temperature, Paspalum vaginatum, tissue culture
Abstract. Cold stress is a major factor limiting the growth of warm-season turfgrass species. Cold tolerance in warmseason turfgrass species could be improved through in vitro selection for somaclonal variations. The objectives of this study were to establish an effective in vitro culture protocol for generating plants from calli using mature seeds of seashore paspalum (Paspalum vaginatum) and to determine whether in vitro cold selection of somaclonal variations would lead to improved cold tolerance in seashore paspalum. The optimal concentrations of supplemental compounds in the culture medium for callus induction, embryogenic callus formation, and plant regeneration were determined. The supplemental compounds included 2,4-dichlorophenoxy acetic acid (2,4-D), 6-benzylaminopurine (6-BA), kinetin (KT), naphthalene-1-acetic acid (NAA), $\mathrm{CuSO}_{4}$, and acidic hydrolysis casein (AHC). The highest rates of callus induction $(97.50 \%)$, embryogenic callus formation $(66.88 \%)$, and regeneration $(55.94 \%)$ were obtained with the supplemental compounds of $3.0 \mathrm{mg} \cdot \mathrm{L}^{-1} 2,4-\mathrm{D}$ and $10.0 \mathrm{mg} \cdot \mathrm{L}^{-1} \mathrm{CuSO}_{4}$ for callus induction; with $3.0 \mathrm{mg} \cdot \mathrm{L}^{-1} 2,4-\mathrm{D}$, $15 \mathrm{mg} \cdot \mathrm{L}^{-1} \mathrm{CuSO}_{4}$, and $1.0 \mathrm{~g} \cdot \mathrm{L}^{-1} \mathrm{AHC}$ for embryogenic callus formation; and with $8.0 \mathrm{mg} \cdot \mathrm{L}^{-1}$ 6-BA, $0.2 \mathrm{mg} \cdot \mathrm{L}^{-1} \mathrm{KT}$, $0.5 \mathrm{mg} \cdot \mathrm{L}^{-1} \mathrm{NAA}$, and $10 \mathrm{mg} \cdot \mathrm{L}^{-1} \mathrm{CuSO}_{4}$ for plant regeneration. Embryogenic calli were subjected to 2 or $6^{\circ} \mathrm{C}$ treatment for 90 days for in vitro cold selection of somaclonal variation. Plants regenerated from calli surviving cold treatment (cold-selected) for 45 or 60 days were then exposed to low temperatures $\left[15 / 10\right.$ or $5 / 3{ }^{\circ} \mathrm{C}$ (day/night)]. Plant variants derived from cold-selected calli exhibited significant improvement in their tolerance to low temperature of either $15 / 10$ or $5 / 3{ }^{\circ} \mathrm{C}$ (day/night), as manifested by higher turf quality, leaf chlorophyll content, and membrane stability as well as lower levels of lipid peroxidation compared with the control plants. This study demonstrated the feasibility of in vitro selection for cold tolerance in seashore paspalum. The cold-tolerant variants could be useful germplasm for breeding programs and further molecular characterization of cold tolerance mechanisms.
\end{abstract}

\begin{abstract}
Abiotic stress is the predominant factor limiting turfgrass growth in many climatic areas. One of the major abiotic stresses in cool temperate regions is low temperature, which can be detrimental for growth of warm-season grass species. Warmseason turfgrasses grown in cool climatic regions enter dormancy early in the fall and green up later in the spring compared with cool-season species (Beard, 1973). Seashore paspalum is a warm-season turfgrass with many desirable traits such as superior tolerance to heat stress, salinity stress, and drought stress; however, this species is sensitive to low temperature stress and often losses turf quality during late fall or early winter in cool climatic regions, which limits its use to warm climatic areas (Duncan and Carrow, 1999). Improving cold tolerance of warm-season turfgrasses such as seashore paspalum is important to expand the range of use and extend the growing season throughout cooler climates.
\end{abstract}

Received for publication 7 Aug. 2013. Accepted for publication 6 Sept. 2013. Thanks go to Jiangsu Agricultural Science and Technology Project for Independent Innovation [CX(13)2033], for funding support. We thank David Jespersen and Patrick Burgess at Rutgers University for the critical review of this manuscript. This project is a collaboration between Nanjing Agricultural University and Center of Turfgrass Science at Rutgers University.

${ }^{1}$ These authors contributed equally to this work.

2Corresponding author. E-mail: huang@aesop.rutgers.edu; nauyzm@njau.edu.
Limited progress has been made in the improvement of cold tolerance in seashore paspalum through traditional breeding efforts as a result of insufficient genetic variability in cold tolerance or the lack of cold-tolerant cultivated germplasm (Duncan and Carrow, 1999). Somaclonal selection is a powerful tool to increase genetic variability with regard to plant stress tolerance (Karp, 1995). Previous studies reported improved cold tolerance through the selection of somaclonal variants in agronomic crops (Bertin and Bouharmont, 1997; Kendall et al., 1990; Lazar et al., 1988). For example, Kendall et al. (1990) showed that plants of winter wheat (Triticum aestivum) regenerated from callus and subsequently exposed to belowfreezing temperature exhibited significant improvement in cold tolerance. Some plants that survived this cryoselection process were genetic variants, which suggest selection at the callus level can contribute to heritable improvement of stress tolerance, although some variations may be epigenetic (Kendall et al., 1990). Additionally, Bertin and Bouharmont (1997) reported enhanced chilling tolerance in rice (Oryza sativa) using somaclonal variations and in vitro selection. Cold tolerance of warm-season turfgrass could be improved through in vitro selection for somaclonal variations under cold treatment. However, in vitro selection for somaclonal variations of cold tolerance is not well documented in turfgrass species. 
An effective and efficient tissue culture and regeneration system is required for the in vitro selection of somaclonal variations. Callus induction, embryogenic callus formation, and plant regeneration require specific concentrations of plant growth regulators such as auxin and cytokinins or their synthetic analogs such as 2,4-D and 6-BA in the culture medium (Murashige and Skoog, 1962; Neibaur et al., 2008). In addition to plant growth regulators, the use of $\mathrm{CuSO}_{4}$ in culture medium was found to stimulate callus induction, proliferation, somatic embryogenesis, and regeneration in some monocotyledonous plants (Dahleen, 1995; Sahrawat and Chand, 1999; Tahiliani and Kothari, 2004). Specific ingredients for culture media likely vary depending on explant type such as seed vs. vegetative organs or inflorescence or differences in genetic composition (Neibaur et al., 2008; Olesen et al., 1995; Zeng et al., 2009). A system for callus induction and plant regeneration has been developed for several turfgrass species, including seashore paspalum (Cardona and Duncan, 1997; Neibaur et al., 2008), perennial ryegrass [Lolium perenne (Olesen et al., 1995; Zeng et al., 2009)], zoysiagrass [Zoysia matrella (Chai et al., 2011)], centipede grass [Eremochloa ophiuroides (Barampuram et al., 2009)], kentucky bluegrass [Poa pratensis (Van Ark et al., 1991)], and creeping bentgrass [Agrostis stolonifera (Zhong et al., 1991)]. Mature seeds and immature inflorescence or embryos are used as explants in in vitro culture systems. The selection of somaclonal variations using seeds as explants offers several advantages over using immature inflorescence or embryos in grass species (Bai and Qu, 2001; Ha et al., 2001). For seashore paspalum seeds produced from outcrossing, use of seeds as explants may generate a wider range of somaclonal variation as compared with using vegetative organs. In addition, mature seeds are likely to be readily available as the source of explants in all seasons and are therefore considered one of the most efficient sources of explants for in vitro culture or somatic embryogenesis in grass species (Bai and Qu, 2001). However, an effective method for callus induction, embryogenic callus formation, and plant regeneration from mature seeds that can be successfully used in in vitro culture selection for seashore paspalum, particularly for in vitro selection of cold tolerance, is not yet available. The establishment of an efficient in vitro selection system is a prerequisite for increasing genetic variability of stress tolerance through somaclonal selection or genetic transformation.

The objectives of this study were to establish an effective in vitro culture protocol for generating plants from calli using mature seeds of seashore paspalum and to determine whether in vitro cold selection of somaclonal variations would lead to improved cold tolerance in seashore paspalum.

\section{Materials and Methods}

\section{Experiments for tissue culture and plant regeneration}

Sterilization of ExPlants. Mature seeds of seashore paspalum 'Sea Spray' were used as explant materials. Seeds were immersed in distilled water for 16 to $24 \mathrm{~h}$ at $25{ }^{\circ} \mathrm{C}$ to pots. followed by $2 \mathrm{~min}$ immersion in $70 \%$ ethanol and then rinsed three times with sterile distilled water. Then, seeds were immersed in $2 \% \mathrm{NaClO}$ solution for $30 \mathrm{~min}$ on a shaker at $25{ }^{\circ} \mathrm{C}$ and subsequently rinsed six to eight times with sterile distilled water.

SEed Germination, Callus induction, and EMbryogeniC CALluS FORMATION. Seed germination, callus induction, and embryogenic callus formation (Fig. 1A-C) were performed using Murashige and Skoog (MS) tissue-culture medium (Murashige and Skoog, 1962). The medium included the following ingredients: $1900 \mathrm{mg} \cdot \mathrm{L}^{-1} \mathrm{KNO}_{3}, 1650 \mathrm{mg} \cdot \mathrm{L}^{-1}$ $\mathrm{NH}_{4} \mathrm{NO}_{3}, 170 \mathrm{mg} \cdot \mathrm{L}^{-1} \mathrm{KH}_{2} \mathrm{PO}_{4}, 370 \mathrm{mg} \cdot \mathrm{L}^{-1} \mathrm{Mg} \cdot \mathrm{SO}_{4} \cdot 7 \mathrm{H}_{2} \mathrm{O}$, $440 \mathrm{mg} \cdot \mathrm{L}^{-1} \mathrm{CaCl}_{2} \cdot 2 \mathrm{H}_{2} \mathrm{O}, 0.83 \mathrm{mg} \cdot \mathrm{L}^{-1} \mathrm{KI}, 6.2 \mathrm{mg} \cdot \mathrm{L}^{-1} \mathrm{H}_{3} \mathrm{BO}_{3}$, $22.3 \mathrm{mg} \cdot \mathrm{L}^{-1} \mathrm{MnSO}_{4} \cdot 4 \mathrm{H}_{2} \mathrm{O}, 8.6 \mathrm{mg} \cdot \mathrm{L}^{-1} \mathrm{ZnSO}_{4} \cdot 7 \mathrm{H}_{2} \mathrm{O}, 0.25 \mathrm{mg} \cdot \mathrm{L}^{-1}$ $\mathrm{Na}_{2} \mathrm{MoO}_{4} \cdot 2 \mathrm{H}_{2} \mathrm{O}, 0.025 \mathrm{mg} \cdot \mathrm{L}^{-1} \mathrm{CuSO}_{4} \cdot 5 \mathrm{H}_{2} \mathrm{O}, 0.025 \mathrm{mg} \cdot \mathrm{L}^{-1}$ $\mathrm{CoCl}_{2} \cdot 6 \mathrm{H}_{2} \mathrm{O}$, $37.3 \mathrm{mg} \cdot \mathrm{L}^{-1} \mathrm{Na}_{2}$ EDTA, $27.8 \mathrm{mg} \cdot \mathrm{L}^{-1} \mathrm{FeSO}_{4} \cdot 7 \mathrm{H}_{2} \mathrm{O}$, $100 \mathrm{mg} \cdot \mathrm{L}^{-1}$ inositol, $2 \mathrm{mg} \cdot \mathrm{L}^{-1}$ glycine, $0.1 \mathrm{mg} \cdot \mathrm{L}^{-1}$ thiamine $\mathrm{HCl}$, $0.5 \mathrm{mg} \cdot \mathrm{L}^{-1}$ niacin, $0.5 \mathrm{mg} \cdot \mathrm{L}^{-1}$ pyridoxine $\mathrm{HCl}, 30 \mathrm{~g} \cdot \mathrm{L}^{-1}$ sucrose, and $7 \mathrm{~g} \cdot \mathrm{L}^{-1}$ agar.

Two experiments were conducted for tissue culture and plant regeneration. The first experiment was designed to determine the optimal concentration of each supplemental compound (2,4-D, 6-BA, KT, or NAA; $\mathrm{CuSO}_{4}$; and $\mathrm{AHC}$ ) affecting seed germination, callus induction, and embryogenic callus formation and the second experiment was performed to determine the optimal composition of the supplemental compounds. In the first experiment, the culture medium included one of four concentrations of each of these aforementioned compounds to determine the optimal concentration of each supplemental compound in an four $\times$ four orthogonal design (four supplemental compounds and four concentrations of each compound) (Table 1). The concentrations of each supplemental compound were selected based on previous research in turfgrass species (Barampuram et al., 2009; Cardona and Duncan, 1997; Chai et al., 2011; Neibaur et al., 2008; Olesen et al., 1995; Van Ark et al., 1991; Zeng et al., 2009). Each of the four concentrations for each compound was replicated in 14 petri
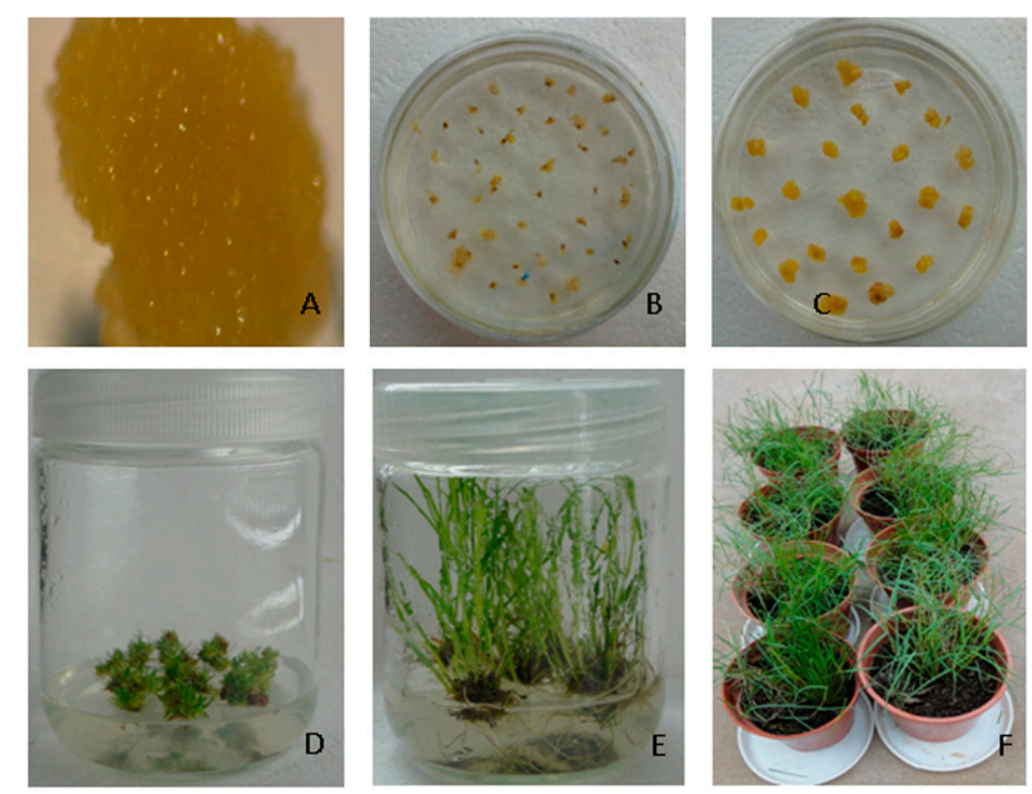

Fig. 1. Establishment of tissue culture and regeneration system of seashore paspalum 'Sea Spray': (A) seeds as explants in the culture medium, (B) induction of callus, (C) subculture of callus, (D) embryogenic callus formation, (E) regenerated plants, and (F) regenerated plants transplanted 
Table 1. The concentrations of supplemental compounds in the culture medium in an orthogonal experimental design for seed germination, callus induction, and embryogenic callus formation in seashore paspalum 'Sea Spray'.

\begin{tabular}{lcccc}
\hline & \multicolumn{4}{c}{ Supplemental compound } \\
\cline { 2 - 5 } Levels & $\begin{array}{c}2,4-\mathrm{D} \\
\left(\mathrm{mg} \cdot \mathrm{L}^{-1}\right)\end{array}$ & $\begin{array}{c}6-\mathrm{BA} \\
\left(\mathrm{mg} \cdot \mathrm{L}^{-1}\right)\end{array}$ & $\begin{array}{c}\mathrm{CuSO} \\
\left(\mathrm{mg} \cdot \mathrm{L}^{-1}\right)\end{array}$ & $\begin{array}{c}\mathrm{AHC} \\
\left(\mathrm{g} \cdot \mathrm{L}^{-1}\right)\end{array}$ \\
\hline 1 & 0 & 0 & 0 & 0 \\
2 & 2.0 & 0.1 & 10.0 & 0.1 \\
3 & 3.0 & 0.5 & 12.5 & 0.5 \\
4 & 4.0 & 1.0 & 15.0 & 1.0 \\
\hline
\end{tabular}

2,4-D = 2,4-dichlorophenoxy acetic acid; 6-BA = 6-benzylaminopurine; $\mathrm{AHC}=$ acidic hydrolysis casein.

dishes and each dish contained 30 seeds for callus induction and 20 calli from 20 seeds for embryogenic callus formation. Sterilized seeds were placed in the MS medium supplemented with 2,4-D, 6-BA, $\mathrm{CuSO}_{4}$, or $\mathrm{AHC}$, and germination rate was recorded after $14 \mathrm{~d}$ as described below. Callus induction and subculture were performed in darkness at $28^{\circ} \mathrm{C}$ in an incubator (Ningbo Hai Shu Sai Fu Instrument \& Equipment, Ningbo, China). Callus induction rate and embryonic callus induction rate were recorded at $30 \mathrm{~d}$ of culture.

The optimal concentration for each of the four compounds determined in the first experiment was combined in one culture medium and the effectiveness of the optimal composition of supplemental compounds on callus induction and embryogenic callus formation was further confirmed in the second experiment. Each treatment combining the optimal concentration of four supplemental compounds was replicated 10 times with 30 mature seeds in each replicate for callus induction and 20 calli for embryogenic callus formation.

Germination rate (percent) was calculated as (number of germinating seeds/total number of seed per petri dish) $\times$ 100. Callus induction percentage is calculated as (number of calli/number of germinating seeds) $\times 100$. The percentage of embryogenic calli was calculated as (number of embryogenic calli/number of germinating seeds) $\times 100$. Plant regeneration rate was expressed as (number of callus forming shoots/number of germinating seeds) $\times 100$.

Plant regeneration. The embryogenic calli were subcultured twice and then transferred into the MS medium supplemented with NAA, 6-BA, KT, and $\mathrm{CuSO}_{4}$ (Fig. 1D-E). To determine the optimal concentration of these supplemental compounds affecting plant regeneration from embryogenic callus, the medium was supplemented with four concentrations of 6-BA, $\mathrm{KT}, \mathrm{CuSO}_{4}$, and NAA. An orthogonal experiment design including four supplemental compounds and four concentrations of each compound was used (Table 2). Each concentration for each supplemental compound was repeated in 14 petri dishes (replicates) and each dish included 20 calli. Calli were kept in a growth chamber (Ningbo Hai Shu Sai Fu Instrument \& Equipment) set at 16-h photoperiod, photosynthetically active radiation $(P A R)$ of $400 \mu \mathrm{mol} \cdot \mathrm{m}^{-2} \cdot \mathrm{s}^{-1}$, and temperature of $28{ }^{\circ} \mathrm{C}$. When shoots and roots were formed, plant regeneration rate was recorded.

\section{Experiments for testing cold tolerance of plants derived from cold-selected calli}

IN VITRO COLD SELECTION OF CALLI AND REGENERATED PLANTS. Embryogenic calli were cultured at $6 \pm 1$ or $2 \pm 1{ }^{\circ} \mathrm{C}$ for 0,30 , $45,60,75$, or $90 \mathrm{~d}$. Each treatment was replicated in 10 petri
Table 2. The concentrations of supplemental compounds in the culture medium in the orthogonal experimental design for plant regeneration in seashore paspalum 'Sea Spray'.

\begin{tabular}{lcccc}
\hline & \multicolumn{4}{c}{ Supplemental compounds } \\
\cline { 2 - 5 } Levels & $\begin{array}{c}6-\mathrm{BA} \\
\left(\mathrm{mg} \cdot \mathrm{L}^{-1}\right)\end{array}$ & $\begin{array}{c}\mathrm{KT} \\
\left(\mathrm{mg} \cdot \mathrm{L}^{-1}\right)\end{array}$ & $\begin{array}{c}\mathrm{CuSO} \\
\left(\mathrm{mg} \cdot \mathrm{L}^{-1}\right)\end{array}$ & $\begin{array}{c}\mathrm{NAA} \\
\left(\mathrm{mg} \cdot \mathrm{L}^{-1}\right)\end{array}$ \\
\hline 1 & 0 & 0 & 0 & 0 \\
2 & 4.0 & 0.05 & 10.0 & 0.1 \\
3 & 6.0 & 0.1 & 12.5 & 0.2 \\
4 & 8.0 & 0.2 & 15.0 & 0.5 \\
\hline $2,4-\mathrm{D}=2,4$ & dichlorophenoxy
\end{tabular}

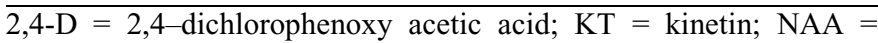
naphthalene-1-acetic acid.

dishes and 20 calli per dish. All materials were cultured in the dark and further subcultured every $15 \mathrm{~d}$. Callus subculture medium was MS medium supplemented with 2,4-D, $\mathrm{CuSO}_{4}$, and AHC. Calli were then transferred to the regeneration medium for the regeneration of plants. Regeneration rate of plants from the calli cultured at either 6 or $2{ }^{\circ} \mathrm{C}$ was then recorded. After plants formed shoots and roots, 80 healthy and uniform-sized plants derived from 80 different calli were transferred to pots filled with a mixture of loamy soil and sand (1:1) and maintained at $30{ }^{\circ} \mathrm{C}$ in growth chambers. The photoperiod was $16 \mathrm{~h}$ and $P A R$ was $622 \mu \mathrm{mol} \cdot \mathrm{m}^{-2} \cdot \mathrm{s}^{-1}$ in the growth chamber.

Evaluation of COLD tOlERANCE IN PLANTS REgenerated FROM COLD-SELECTED CALLI vs. CONTROL PLANTS. The initial screening for cold tolerance of selected 80 variant lines regenerated from cold-selected calli was performed by exposing 40-d-old regenerated plants to low temperature at $5 / 3{ }^{\circ} \mathrm{C}$ for $7 \mathrm{~d}$ in a growth chamber and visual turf quality was recorded. A cold-selected variant line with highest turf quality rating (6.5) was selected from the initial screening test and then propagated to generate plant materials for further evaluation of physiological responses to cold stress. The non-cold-selected plants (control plants regenerated from calli exposed to $28^{\circ} \mathrm{C}$ ) and plants regenerated from cold-selected calli at $2{ }^{\circ} \mathrm{C}$ for 45 or $60 \mathrm{~d}$ were grown at two low-temperature treatments for $16 \mathrm{~d}$ at $15 / 10$ or $5 / 3{ }^{\circ} \mathrm{C}$ (day/night) in growth chambers. The control plants and the cold-selected variants were derived from the same original callus to ensure uniform genetic background through subculture of the original callus. Each of the two growing temperature treatments $\left(15 / 10\right.$ or $\left.5 / 3{ }^{\circ} \mathrm{C}\right)$ was replicated in four pots with 20 plants in each pot. Several commonly used growth and physiological indicators for cold tolerance were evaluated to compare cold tolerance between the control plants and plants regenerated from calli cultured at $2{ }^{\circ} \mathrm{C}$ for 45 or $60 \mathrm{~d}$, as described below.

Turf quality (TQ) is a commonly used indicator of overall plant performance in turfgrass. It was rated visually on the scale from 1 to 9 with 1 being completely desiccated brown turf canopy and 9 being healthy plants with dark green and turgid leaf blades and a dense turf canopy (Beard, 1973).

Leaf cellular membrane stability was determined by measuring electrolyte leakage (EL) of leaves according to the procedure set forth by Blum and Ebercon (1981). For EL, fresh leaves $(0.2 \mathrm{~g})$ were collected, rinsed with deionized water, and immersed in $40 \mathrm{~mL}$ deionized water. The initial conductivity of the incubation solution $\left(\mathrm{C}_{\text {initial }}\right)$ was measured using a conductivity meter (DDS-12A; Shanghai Kangyi Instrument \& Equipment, Shanghai, China) after incubation in deionized 
water for $24 \mathrm{~h}$ on a shaker. Leaves were then killed at $100{ }^{\circ} \mathrm{C}$ for $30 \mathrm{~min}$ in a water bath and again shaken for $12 \mathrm{~h}$. The conductivity of killed tissues $\left(\mathrm{C}_{\max }\right)$ was then measured again. $\mathrm{EL}$ (percent) was calculated as $\left(\mathrm{C}_{\text {initial }} / \mathrm{C}_{\max }\right) \times 100$.

For determination of leaf chlorophyll content, fresh leaves $(0.2 \mathrm{~g})$ were detached from plants and then soaked in dimethyl sulphoxide in darkness for $72 \mathrm{~h}$ to extract chlorophyll. The absorbance of the extraction solution was measured at 663 and $645 \mathrm{~nm}$, which was used to calculate chlorophyll content according to Arnon (1949).

Lipid peroxidation was measured based on malondialdehyde (MDA) content of leaves according to Dhindsa and Matowe (1981) with modifications. Fresh leaves ( $0.40 \mathrm{~g}$ fresh weight) was ground in liquid nitrogen to a fine powder using a mortar and pestle and extraction was performed with $4 \mathrm{~mL}$ of extraction buffer ( $50 \mathrm{~mm}$ potassium phosphate, $1 \mathrm{~mm}$ ethylenediaminetetraacetic acid, $1 \%$ polyvinylpyrrolidone, $1 \mathrm{~mm}$ dithiothreitol, and $1 \mathrm{~mm}$ phenylmethylsulfonyl; $\mathrm{pH} 7.8$ ). The extractions were centrifuged at $15,000 \mathrm{~g}_{\mathrm{n}}$ for $30 \mathrm{~min}$ at $4{ }^{\circ} \mathrm{C}$, and supernatant was collected for MDA content measurement. A $0.8-\mathrm{mL}$ aliquot of supernatant was mixed with $1.6 \mathrm{~mL}$ of $20 \%$ trichloroacetic acid containing $0.5 \%$ thiobarbituric acid and the mixture heated at $95{ }^{\circ} \mathrm{C}$ for $30 \mathrm{~min}$, quickly cooled on ice, and then centrifuged at $10,000 \mathrm{~g}$ for $10 \mathrm{~min}$. The absorbance of the supernatant was read at 532 and $600 \mathrm{~nm}$ and MDA concentration calculated using an extinction coefficient of $155 \mathrm{~mm}^{-1} / \mathrm{cm}$ (Health and Packer, 1968).

Statistical analysis. Treatment effects were determined by analysis of variance according to the general linear model procedure of SAS (Version 9.2; SAS Institute, Cary, NC). Differences between means were separated by Fisher's protected least significance difference test at the $0.05 P$ level.

\section{Results}

OPTIMAL CONCENTRATION AND COMPOSITION OF 2,4-D, 6-BA, $\mathrm{CUSO}_{4}$, AND AHC IN THE CULTURE MEDIUM FOR SEED GERMINATION. Seed germination, callus induction, and embryogenic callus formation were tested in culture media containing four concentrations of 2,4-D, 6-BA, $\mathrm{CuSO}_{4}$, and $\mathrm{AHC}$ including a control treatment with no supplemental compounds added. After 14 $\mathrm{d}$ of culture, there was no difference in seed germination rate among the three concentrations of 2,4-D and all three treatments had significantly higher germination compared with the control medium (Table 3 ). Seed germination rate declined with increasing 6-BA concentrations from 0.1 to $1.0 \mathrm{mg} \cdot \mathrm{L}^{-1}$. Under $\mathrm{CuSO}_{4}$ treatments, the highest germination rate was found at $2 \mathrm{mg} \cdot \mathrm{L}^{-1}$, which was significantly higher than at two other concentrations but did not differ from that of the control medium. Seed germination rate was significantly higher in the culture medium containing $0.5 \mathrm{~g} \cdot \mathrm{L}^{-1}$ AHC compared with all other AHC concentrations including controls.

The optimal composition or effectiveness of culture medium containing the optimal concentration of 2,4-D and AHC was further tested in the second experiment, whereas 6-BA and $\mathrm{CuSO}_{4}$, which inhibited seed germination, were excluded from the culture medium (Table 4$)$. Seed germination rate $(97.50 \%)$ was highest in the culture medium containing $2.0 \mathrm{mg} \cdot \mathrm{L}^{-1} 2,4-\mathrm{D}$ and $0.5 \mathrm{~g} \cdot \mathrm{L}^{-1} \mathrm{AHC}$, confirming this composition of supplemental compound in the culture medium was most effective in promoting seed germination.
Table 3. Effects of varied concentrations of 2,4-dichlorophenoxy acetic acid (2,4-D), 6-benzylaminopurine (6-BA), $\mathrm{CuSO}_{4}$, and acidic hydrolysis casein (AHC) on seed germination rates for seashore paspalum 'Sea Spray'.

\begin{tabular}{lllll}
\hline & \multicolumn{4}{c}{ Germination rate (\%) } \\
\cline { 2 - 5 } Levels $^{\mathrm{z}}$ & 2,4-D & 6-BA & $\mathrm{CuSO}_{4}$ & $\mathrm{AHC}$ \\
\hline 1 & $90.06 \mathrm{~b}^{\mathrm{y}}$ & $93.31 \mathrm{ab}$ & $94.19 \mathrm{ab}$ & $93.81 \mathrm{~b}$ \\
2 & $94.38 \mathrm{a}$ & $95.19 \mathrm{a}$ & $95.44 \mathrm{a}$ & $93.13 \mathrm{~b}$ \\
3 & $95.69 \mathrm{a}$ & $93.69 \mathrm{ab}$ & $92.50 \mathrm{~b}$ & $95.56 \mathrm{a}$ \\
4 & $95.19 \mathrm{a}$ & $93.13 \mathrm{~b}$ & $93.19 \mathrm{~b}$ & $92.81 \mathrm{~b}$
\end{tabular}

z2,4-D: $1=0 \mathrm{mg} \cdot \mathrm{L}^{-1}, 2=2.0 \mathrm{mg} \cdot \mathrm{L}^{-1}, 3=3.0 \mathrm{mg} \cdot \mathrm{L}^{-1}, 4=4.0 \mathrm{mg} \cdot \mathrm{L}^{-1} ; 6-\mathrm{BA}$ : $1=0 \mathrm{mg} \cdot \mathrm{L}^{-1}, 2=0.1 \mathrm{mg} \cdot \mathrm{L}^{-1}, 3=0.5 \mathrm{mg} \cdot \mathrm{L}^{-1}, 4=1.0 \mathrm{mg} \cdot \mathrm{L}^{-1} ; \mathrm{CuSO}_{4}$ : $1=0 \mathrm{mg} \cdot \mathrm{L}^{-1}, 2=10.0 \mathrm{mg} \cdot \mathrm{L}^{-1}, 3=12.5 \mathrm{mg} \cdot \mathrm{L}^{-1}, 4=15.0 \mathrm{mg} \cdot \mathrm{L}^{-1}$; AHC: $1=0 \mathrm{~g} \cdot \mathrm{L}^{-1}, 2=0.1 \mathrm{~g} \cdot \mathrm{L}^{-1}, 3=0.5 \mathrm{~g} \cdot \mathrm{L}^{-1}, 4=1.0 \mathrm{~g} \cdot \mathrm{L}^{-1}$.

${ }^{y}$ Means within a column marked with different letters were significantly different between concentrations for each compound based on least significant difference test at $P \leq 0.05$.

Table 4. Effects of the combination of compounds or compositions of the culture medium supplements on seed germination, callus induction, and embryogenic callus formation in seashore paspalum 'Sea Spray'.

\begin{tabular}{lccc}
\hline & $\begin{array}{c}\text { Germination ratio } \\
(\text { mean } \pm \mathrm{SE})\end{array}$ & $\begin{array}{c}\text { Callus } \\
\text { induction ratio } \\
(\text { mean } \pm \mathrm{SE})\end{array}$ & $\begin{array}{c}\text { Embryogenic } \\
\text { callus induction } \\
\text { ratio }(\text { mean } \pm \mathrm{SE})\end{array}$ \\
\hline $\mathrm{C} 1$ & $97.50 \pm 2.04 \mathrm{a}^{\mathrm{y}}$ & $86.25 \pm 7.22 \mathrm{c}$ & $30.00 \pm 1.02 \mathrm{c}$ \\
$\mathrm{C} 2$ & $91.25 \pm 1.44 \mathrm{~b}$ & $97.50 \pm 1.20 \mathrm{a}$ & $52.50 \pm 1.77 \mathrm{~b}$ \\
$\mathrm{C} 3$ & $88.13 \pm 2.39 \mathrm{~b}$ & $93.13 \pm 6.25 \mathrm{~b}$ & $66.88 \pm 1.57 \mathrm{a}$
\end{tabular}

${ }^{\mathrm{z}} \mathrm{C} 1=2.0 \mathrm{mg} \cdot \mathrm{L}^{-1} 2,4$-dichlorophenoxy acetic acid $(2,4-\mathrm{D})+0.0 \mathrm{mg} \cdot \mathrm{L}^{-1}$ 6-benzylaminopurine $(6-\mathrm{BA})+0.0 \mathrm{mg} \cdot \mathrm{L}^{-1} \mathrm{CuSO}_{4},+0.5 \mathrm{~g} \cdot \mathrm{L}^{-1}$ acidic hydrolysis casein $(\mathrm{AHC}) ; \mathrm{C} 2=3.0 \mathrm{mg} \cdot \mathrm{L}^{-1} 2,4-\mathrm{D}+0.0 \mathrm{mg} \cdot \mathrm{L}^{-1} 6-\mathrm{BA}+$ $10.0 \mathrm{mg} \cdot \mathrm{L}^{-1} \mathrm{CuSO}_{4},+0.0 \mathrm{~g} \cdot \mathrm{L}^{-1} \mathrm{AHC} ; \mathrm{C} 3=3.0 \mathrm{mg} \cdot \mathrm{L}^{-1} 2,4-\mathrm{D}+$ $0.0 \mathrm{mg} \cdot \mathrm{L}^{-1} 6-\mathrm{BA}+15.0 \mathrm{mg} \cdot \mathrm{L}^{-1} \mathrm{CuSO}_{4},+1.0 \mathrm{~g} \cdot \mathrm{L}^{-1} \mathrm{AHC}$.

${ }^{y}$ Mean within a column marked with different letters were significantly different between different compositions based on least significant difference test at $P \leq 0.05$.

OPTIMAL CONCENTRATION AND COMPOSITION OF 2,4-D, 6-BA, $\mathrm{CUSO}_{4}$, AND AHC IN THE CULTURE MEDIUM FOR CALLUS INDUCTION. Calli formation was first observed $7 \mathrm{~d}$ after cultures were made (Fig. 1B). The experiment testing the optimal concentration of individual compounds showed that addition of 2,4-D in the culture medium enhanced callus induction with the highest callus induction percentage (96.43\%) when 2,4-D was added at $3.0 \mathrm{mg} \cdot \mathrm{L}^{-1}$ (Table 5). Lower concentrations of 6-BA at $1.0 \mathrm{mg} \cdot \mathrm{L}^{-1}$ and $0.5 \mathrm{mg} \cdot \mathrm{L}^{-1}$ had no significant effects on callus induction compared with the control medium, but the highest concentration at $1.0 \mathrm{mg} \cdot \mathrm{L}^{-1}$ significantly reduced the percentage of callus induction. Callus induction percentage of the medium containing any concentration of $\mathrm{CuSO}_{4}$ was significantly higher than that of the control medium, but there were no significant differences among the three $\mathrm{CuSO}_{4}$ concentrations. Induction percentage increased with $\mathrm{AHC}$ concentrations, but it was not significantly different between the highest concentration of $\mathrm{AHC}$ and the control medium.

Effectiveness of the medium containing the optimal concentration of 2,4-D (3.0 mg. $\left.\mathrm{L}^{-1}\right)$ and $\mathrm{CuSO}_{4}\left(10.0 \mathrm{mg} \cdot \mathrm{L}^{-1}\right)$ that promoted callus induction was further tested in the second experiment (Table 4). The results confirmed that the culture medium containing both optimal concentrations of 2,4-D and $\mathrm{CuSO}_{4}$ indeed had the highest callus induction percentage 
(97.50\%) compared with the control medium and the two other compositions.

OPTIMAL CONCENTRATION AND COMPOISTION OF 2,4-D, 6-BA, $\mathrm{CUSO}_{4}$, AND AHC IN THE CULTURE MEDIUM FOR EMBRYOGENIC CALLUS INDUCTION. Embryogenic calli were formed within $\approx 28 \mathrm{~d}$ of subculture (Fig. 1D). In the first experiment testing for the optimal concentration of individual compounds, the supplement of 2,4-D in the culture medium enhanced the formation of embryogenic callus and the percentage of embryogenic callus was highest at the moderate level of 2,4-D $\left(3.0 \mathrm{mg} \cdot \mathrm{L}^{-1}\right)$ (Table 6). The culture medium with all three concentrations of 6-BA had a significantly lower percentage of embryogenic callus, suggesting that 6-BA had inhibitory effects on embryogenic callus formation. The percentage of embryogenic callus significantly increased with increasing concentrations of $\mathrm{CuSO}_{4}$ and $\mathrm{AHC}$, indicating both compounds promoted embryogenic callus formation.

The optimal concentration for 2,4-D (3.0 mg. $\left.\mathrm{L}^{-1}\right), \mathrm{CuSO}_{4}$ $\left(15 \mathrm{mg} \cdot \mathrm{L}^{-1}\right)$, and AHC $\left(1.0 \mathrm{~g} \cdot \mathrm{L}^{-1}\right)$ was combined in one culture medium to determine the effectiveness of this composition for embryogenic callus formation in the second experiment, whereas 6-BA was excluded from the culture medium as a result of its inhibitory effects. The culture medium containing

Table 5. Effects of different compounds in the culture medium at four levels of concentrations for each compound on callus induction percentage in seashore paspalum 'Sea Spray'.

\begin{tabular}{lcccc}
\hline & \multicolumn{4}{c}{ Callus induction percentage (\%) } \\
\cline { 2 - 5 } Levels $^{\mathrm{z}}$ & $2,4-\mathrm{D}$ & $6-\mathrm{BA}$ & $\mathrm{CuSO}_{4}$ & $\mathrm{AHC}$ \\
\hline 1 & $0.00 \mathrm{~d}^{\mathrm{y}}$ & $73.41 \mathrm{a}$ & $62.96 \mathrm{~b}$ & $71.70 \mathrm{ab}$ \\
2 & $94.01 \mathrm{~b}$ & $72.54 \mathrm{a}$ & $71.44 \mathrm{a}$ & $69.21 \mathrm{~b}$ \\
3 & $96.43 \mathrm{a}$ & $69.75 \mathrm{a}$ & $71.81 \mathrm{a}$ & $65.13 \mathrm{c}$ \\
4 & $89.11 \mathrm{c}$ & $63.85 \mathrm{~b}$ & $73.34 \mathrm{a}$ & $72.52 \mathrm{a}$
\end{tabular}

2,4-dichlorophenoxy acetic acid (2,4-D): $1=0 \mathrm{mg} \cdot \mathrm{L}^{-1}, 2=2.0 \mathrm{mg} \cdot \mathrm{L}^{-1}$, $3=3.0 \mathrm{mg} \cdot \mathrm{L}^{-1}, 4=4.0 \mathrm{mg} \cdot \mathrm{L}^{-1} ; 6$-benzylaminopurine $(6-\mathrm{BA}): 1=$ $0 \mathrm{mg} \cdot \mathrm{L}^{-1}, 2=0.1 \mathrm{mg} \cdot \mathrm{L}^{-1}, 3=0.5 \mathrm{mg} \cdot \mathrm{L}^{-1}, 4=1.0 \mathrm{mg} \cdot \mathrm{L}^{-1} ; \mathrm{CuSO}_{4}: 1=$ $0 \mathrm{mg} \cdot \mathrm{L}^{-1}, 2=10.0 \mathrm{mg} \cdot \mathrm{L}^{-1}, 3=12.5 \mathrm{mg} \cdot \mathrm{L}^{-1}, 4=15.0 \mathrm{mg} \cdot \mathrm{L}^{-1}$; acidic hydrolysis casein (AHC): $1=0 \mathrm{~g} \cdot \mathrm{L}^{-1}, 2=0.1 \mathrm{~g} \cdot \mathrm{L}^{-1}, 3=0.5 \mathrm{~g} \cdot \mathrm{L}^{-1}, 4=$ $1.0 \mathrm{~g} \cdot \mathrm{L}^{-1}$.

${ }^{y}$ Mean within a column marked with different letters were significantly different between concentrations for each compound based on least significant difference test at $P \leq 0.05$.

Table 6. Effects of different supplemental compounds in the culture medium at four levels of concentrations for each compound on the percentage of embryogenic callus induction in seashore paspalum 'Sea Spray'.

\begin{tabular}{lcccc}
\hline & \multicolumn{4}{c}{ Embryogenic callus induction (\%) } \\
\cline { 2 - 5 } Levels $^{\mathrm{z}}$ & $2,4-\mathrm{D}$ & $6-\mathrm{BA}$ & $\mathrm{CuSO}_{4}$ & $\mathrm{AHC}$ \\
\hline 1 & $0.00 \mathrm{~d}^{\mathrm{y}}$ & $42.26 \mathrm{a}$ & $20.37 \mathrm{~d}$ & $18.88 \mathrm{c}$ \\
2 & $36.41 \mathrm{c}$ & $34.28 \mathrm{~b}$ & $30.82 \mathrm{c}$ & $30.80 \mathrm{~b}$ \\
3 & $46.73 \mathrm{a}$ & $26.73 \mathrm{c}$ & $34.79 \mathrm{~b}$ & $31.09 \mathrm{~b}$ \\
4 & $41.40 \mathrm{~b}$ & $21.26 \mathrm{~d}$ & $38.56 \mathrm{a}$ & $35.54 \mathrm{a}$
\end{tabular}

z2,4-dichlorophenoxy acetic acid (2,4-D): $1=0 \mathrm{mg} \cdot \mathrm{L}^{-1}, 2=2.0 \mathrm{mg} \cdot \mathrm{L}^{-1}$, $3=3.0 \mathrm{mg} \cdot \mathrm{L}^{-1}, 4=4.0 \mathrm{mg} \cdot \mathrm{L}^{-1} ; 6$-benzylaminopurine $(6-\mathrm{BA}): 1=$ $0 \mathrm{mg} \cdot \mathrm{L}^{-1}, 2=0.1 \mathrm{mg} \cdot \mathrm{L}^{-1}, 3=0.5 \mathrm{mg} \cdot \mathrm{L}^{-1}, 4=1.0 \mathrm{mg} \cdot \mathrm{L}^{-1} ; \mathrm{CuSO}_{4}: 1=$ $0 \mathrm{mg} \cdot \mathrm{L}^{-1}, 2=10.0 \mathrm{mg} \cdot \mathrm{L}^{-1}, 3=12.5 \mathrm{mg} \cdot \mathrm{L}^{-1}, 4=15.0 \mathrm{mg} \cdot \mathrm{L}^{-1}$; acidic hydrolysis casein (AHC): $1=0 \mathrm{~g} \cdot \mathrm{L}^{-1}, 2=0.1 \mathrm{~g} \cdot \mathrm{L}^{-1}, 3=0.5 \mathrm{~g} \cdot \mathrm{L}^{-1}, 4=$ $1.0 \mathrm{~g} \cdot \mathrm{L}^{-1}$.

${ }^{y}$ Mean within a column marked with different letters were significantly different between concentrations for each compound based on least significant difference test at $P \leq 0.05$. the optimal concentration of 2,4-D, $\mathrm{CuSO}_{4}$, and $\mathrm{AHC}$ had the highest percentage of embryogenic callus (66.88\%) among the control medium and the other two medium compositions (Table 4).

Plant regeneration rate. Green shoots were formed from somatic embryos $\approx 21 \mathrm{~d}$ after the callus was transferred to the regeneration medium and was accompanied by prolific formation of root systems. The regeneration rate was enhanced by the addition of $6-\mathrm{BA}$ and $\mathrm{KT}$ to the regeneration medium and the highest rate of regeneration was found in medium with the highest concentration of 6 -BA $\left(8.0 \mathrm{mg} \cdot \mathrm{L}^{-1}\right)$ and $\mathrm{KT}$ $\left(0.2 \mathrm{mg} \cdot \mathrm{L}^{-1}\right)$, both of which were significantly greater than the lower concentrations of 6-BA or KT as well as the control medium (Table 7). The regeneration rate was greatest at the lowest concentration of $\mathrm{CuSO}_{4}$, which itself was significantly higher than the control medium. Only the highest concentration of NAA $\left(0.5 \mathrm{mg} \cdot \mathrm{L}^{-1}\right)$ had significantly greater regeneration than the control medium, whereas the two lower concentrations of NAA did not. These results suggested that the regeneration medium containing the highest concentration of 6-BA $\left(8.0 \mathrm{mg} \cdot \mathrm{L}^{-1}\right)$, KT $\left(0.2 \mathrm{mg} \cdot \mathrm{L}^{-1}\right)$, and NAA $\left(0.5 \mathrm{mg} \cdot \mathrm{L}^{-1}\right)$ and lowest concentration of $\mathrm{CuSO}_{4}\left(10 \mathrm{mg} \cdot \mathrm{L}^{-1}\right)$ was most effective in promoting plant regeneration, obtaining the highest regeneration rate of $53.13 \%$.

EFFECTS OF LOW TEMPERATURE ON PLANT REGENERATION. To determine the effects of cold temperature on plant regeneration rate, calli were subjected to 2 or $6{ }^{\circ} \mathrm{C}$ during the regeneration process. The regeneration rate declined significantly under either low temperature at 2 or $6{ }^{\circ} \mathrm{C}$ and further with longer duration of low temperature (Fig. 2). Regeneration was greater than $90 \%$ at $28{ }^{\circ} \mathrm{C}$ but declined to the lowest $10 \%$ and $30 \%$ at 2 and $6{ }^{\circ} \mathrm{C}$ treatment, respectively. The regeneration percentage at $2{ }^{\circ} \mathrm{C}$ was significantly lower than that at $6{ }^{\circ} \mathrm{C}$ during the entire 90 -d treatment period. The results indicated that prolonged duration of low temperature inhibited plant regeneration but the plants regenerated from the callus that survived the low temperature treatment at $2{ }^{\circ} \mathrm{C}$ could have improved underlying genetic tolerance to cold stress and therefore may be developed into cold-tolerant plants.

Evaluation of COLD TOLERANCE OF Plants Regenerated FROM CALLUS CULTURED AT LOW TEMPERATURE. To determine whether plants selected through an in vitro selection process

Table 7. Effects of different supplemental compounds in the culture medium at four levels of concentrations for each compound on plant regeneration in seashore paspalum 'Sea Spray'.

\begin{tabular}{lcccc}
\hline & \multicolumn{4}{c}{ Regeneration(\%) } \\
\cline { 2 - 5 } Levels $^{\mathrm{z}}$ & $6-\mathrm{BA}$ & $\mathrm{KT}$ & $\mathrm{CuSO}_{4}$ & NAA \\
\hline 1 & $28.44 \mathrm{c}^{\mathrm{y}}$ & $30.31 \mathrm{~b}$ & $31.56 \mathrm{c}$ & $35.31 \mathrm{~b}$ \\
2 & $35.31 \mathrm{~b}$ & $46.25 \mathrm{a}$ & $52.19 \mathrm{a}$ & $34.69 \mathrm{~b}$ \\
3 & $40.00 \mathrm{~b}$ & $46.88 \mathrm{a}$ & $35.63 \mathrm{bc}$ & $36.56 \mathrm{~b}$ \\
4 & $55.94 \mathrm{a}$ & $36.25 \mathrm{~b}$ & $40.31 \mathrm{~b}$ & $53.13 \mathrm{a}$ \\
\hline
\end{tabular}

z2,4-dichlorophenoxy acetic acid (2,4-D): $1=0 \mathrm{mg} \cdot \mathrm{L}^{-1}, 2=2.0 \mathrm{mg} \cdot \mathrm{L}^{-1}$, $3=3.0 \mathrm{mg} \cdot \mathrm{L}^{-1}, 4=4.0 \mathrm{mg} \cdot \mathrm{L}^{-1} ; 6$-benzylaminopurine $(6-\mathrm{BA}): 1=$ $0 \mathrm{mg} \cdot \mathrm{L}^{-1}, 2=0.1 \mathrm{mg} \cdot \mathrm{L}^{-1}, 3=0.5 \mathrm{mg} \cdot \mathrm{L}^{-1}, 4=1.0 \mathrm{mg} \cdot \mathrm{L}^{-1} ; \mathrm{CuSO}_{4}: 1=$ $0 \mathrm{mg} \cdot \mathrm{L}^{-1}, 2=10.0 \mathrm{mg} \cdot \mathrm{L}^{-1}, 3=12.5 \mathrm{mg} \cdot \mathrm{L}^{-1}, 4=15.0 \mathrm{mg} \cdot \mathrm{L}^{-1}$; acidic hydrolysis casein $(\mathrm{AHC}): 1=0 \mathrm{~g} \cdot \mathrm{L}^{-1}, 2=0.1 \mathrm{~g} \cdot \mathrm{L}^{-1}, 3=0.5 \mathrm{~g} \cdot \mathrm{L}^{-1}, 4=$ $1.0 \mathrm{~g} \cdot \mathrm{L}^{-1}$

${ }^{y}$ Mean within a column marked with different letters were significantly different between concentrations for each compound based on least significant difference test at $P \leq 0.05$. 
exhibited improved cold tolerance, the plants with welldeveloped shoot and root systems regenerated from calli cultured at $2{ }^{\circ} \mathrm{C}$ (cold-selected) for 45 or $60 \mathrm{~d}$ were transplanted to pots with a mixture of loamy soil and sand (1:1) and grown under two temperature regimes $\left[5 / 3\right.$ and $15 / 10{ }^{\circ} \mathrm{C}$ (day/night)] for $16 \mathrm{~d}$. Several commonly used indicators of stress tolerance were used, including TQ, EL, chlorophyll content, and lipid peroxidation.

Plants regenerated from cold-selected calli at $2{ }^{\circ} \mathrm{C}$ for $60 \mathrm{~d}$ had significantly higher $\mathrm{TQ}$ at $16 \mathrm{~d}$ of $15^{\circ} \mathrm{C}$ treatment (Fig. 3A)

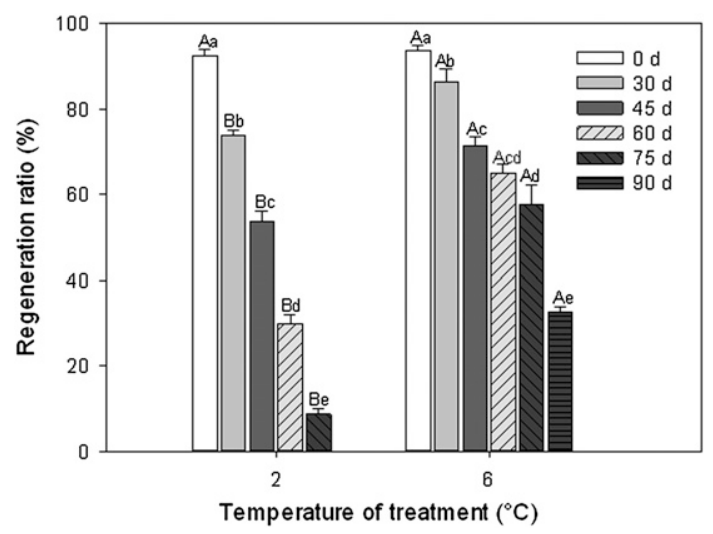

Fig. 2. Effects of low temperatures $\left(2\right.$ and $\left.6{ }^{\circ} \mathrm{C}\right)$ on plant regeneration in seashore paspalum 'Sea Spray'. Different upper case letters represent the significant difference under different temperatures at a given day of treatment. Different lowercase letters represent the significant difference under different days at a given temperature based on least significant difference test at $P \leq$ 0.05 levels.
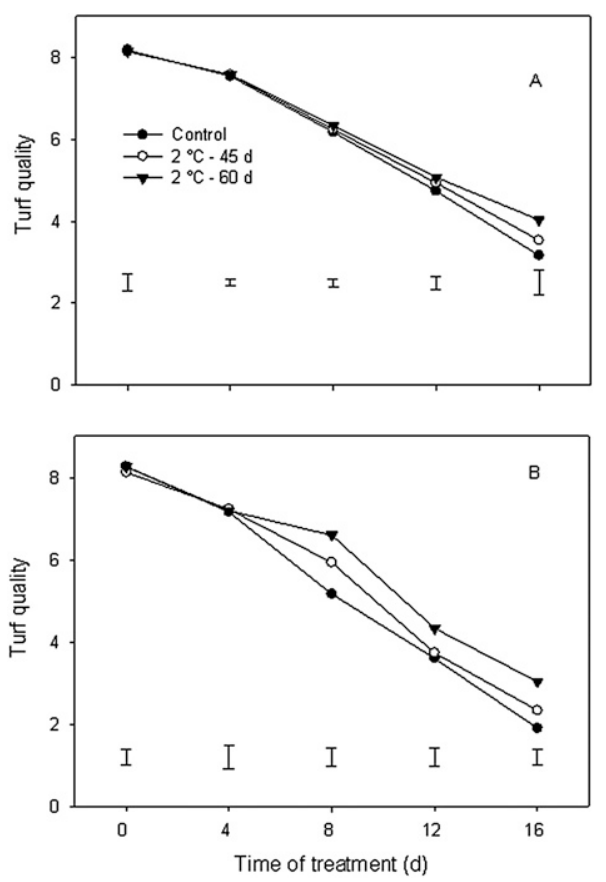

Fig. 3. Turf quality in seashore paspalum 'Sea Spray' plants derived from coldselected calli at $2{ }^{\circ} \mathrm{C}$ for 45 or $60 \mathrm{~d}$ in response to two low growing temperatures (day/night): $15 / 10^{\circ} \mathrm{C}(\mathbf{A})$ and $5 / 3{ }^{\circ} \mathrm{C}(\mathbf{B})$. Turf quality was rated on the scale of 1 to 9 with 9 being the best and 1 being worst. Vertical bars represent the least significant difference values $(P \leq 0.05)$ for comparison between the control plants (non-cold-selected) and the regenerated plants from callus at $2{ }^{\circ} \mathrm{C}$ for 45 or $60 \mathrm{~d}$ at a given day of low growing temperature treatment. and during 8 to $16 \mathrm{~d}$ of $5{ }^{\circ} \mathrm{C}$ treatment (Fig. 3B). Plants regenerated from cold-selected calli at $2{ }^{\circ} \mathrm{C}$ for $45 \mathrm{~d}$ did not exhibit improvement in TQ compared with the control plants under either low growing temperature.

Leaf EL (Fig. 4) and MDA content (Fig. 5) increased in plants exposed to low growing temperature treatment. Plants regenerated from cold-selected calli at $2{ }^{\circ} \mathrm{C}$ for either 45 or $60 \mathrm{~d}$ had significantly lower EL than the control plants at 16 $\mathrm{d}$ of $15{ }^{\circ} \mathrm{C}$ growing temperature treatment (Fig. 4A). MDA content of plants from the cold-selected calli for $60 \mathrm{~d}$ was significantly lower than the control plants at $16 \mathrm{~d}$ of $15{ }^{\circ} \mathrm{C}$ growing temperature treatment (Fig. 5A). The EL and MDA levels of plants regenerated from calli cultured at $2{ }^{\circ} \mathrm{C}$ for either 45 or $60 \mathrm{~d}$ were both significantly lower than those of the control at 12 and $16 \mathrm{~d}$ of $5{ }^{\circ} \mathrm{C}$ growing temperature treatment (Fig. 4B).

Leaf chlorophyll content declined during low growing temperature treatment (Fig. 6). Plants derived from coldselected calli at $2{ }^{\circ} \mathrm{C}$ for 45 or $60 \mathrm{~d}$ had significantly higher chlorophyll content than the control plants at 12 and $16 \mathrm{~d}$ of $15{ }^{\circ} \mathrm{C}$ growing temperature treatment (Fig. 6A). The significant increase in chlorophyll content of the plants from cold-selected calli compared with the control plant was also observed at 8 and $16 \mathrm{~d}$ of $5{ }^{\circ} \mathrm{C}$ growing temperature treatment (Fig. 6B).

\section{Discussion}

Various studies have demonstrated that specific types and quantities of plant growth regulators for callus induction,
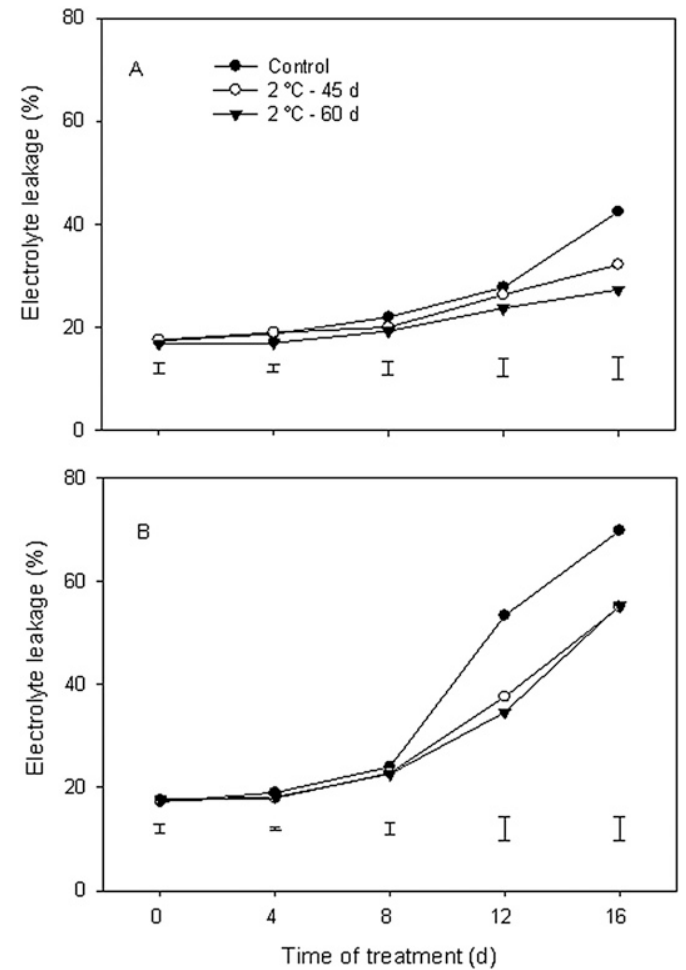

Fig. 4. Leaf electrolyte leakage in seashore paspalum 'Sea Spray' plants derived from cold-selected calli at $2{ }^{\circ} \mathrm{C}$ for 45 or $60 \mathrm{~d}$ in response to two low growing temperatures (day/night): $15 / 10^{\circ} \mathrm{C}(\mathbf{A})$ and $5 / 3{ }^{\circ} \mathrm{C}(\mathbf{B})$. Vertical bars represent the least significant difference values $(P \leq 0.05)$ for comparison between the control plants (non-cold-selected) and the regenerated plants from callus at $2{ }^{\circ} \mathrm{C}$ for 45 or $60 \mathrm{~d}$ at a given day of low growing temperature treatment. 

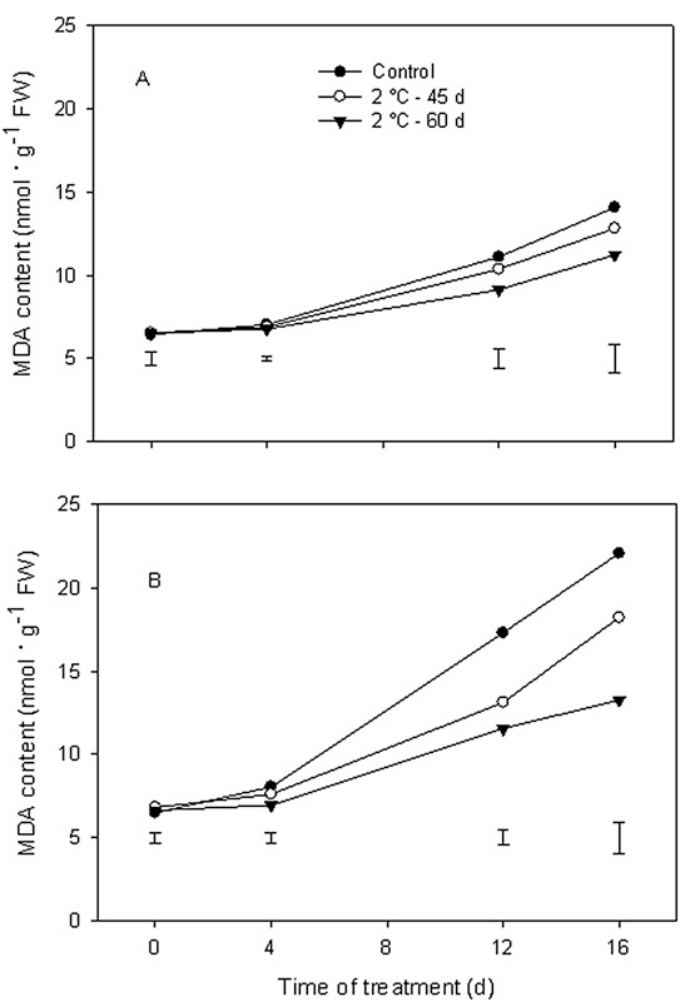

Fig. 5. Leaf lipid peroxidation level measured as the content of malonaldehyde (MDA) in seashore paspalum 'Sea Spray' plants derived from cold-selected calli at $2{ }^{\circ} \mathrm{C}$ for 45 or $60 \mathrm{~d}$ in response to two low growing day/night temperatures: $15 / 10{ }^{\circ} \mathrm{C}(\mathbf{A})$ and $5 / 3{ }^{\circ} \mathrm{C}(\mathbf{B})$. Vertical bars represent the least significant difference values $(P \leq 0.05)$ for comparison between the control plants (non-cold-selected) and the regenerated plants from callus at $2{ }^{\circ} \mathrm{C}$ for 45 or $60 \mathrm{~d}$ at a given day of low growing temperature treatment.

embryogenic callus formation, and plant regeneration vary among plant species or genotypes, source of explants, and culture conditions as discussed in the introduction and in the following. A previous study with seashore paspalum developed a protocol for callus induction using young inflorescence as explants and reported that the highest callus induction percentage $(55 \%)$ was obtained at the rate of $2,4-\mathrm{D}$ of $2.0 \mathrm{mg} \cdot \mathrm{L}^{-1}$ and significant embryogenic callus formation occurred at the moderate concentration of $6-\mathrm{BA}\left(1.0 \mathrm{mg} \cdot \mathrm{L}^{-1}\right)$ in combination with 0.5 to $2.0 \mathrm{mg} \cdot \mathrm{L}^{-1} \mathrm{NAA}$ (Cardona and Duncan, 1997). Neibaur et al. (2008) also developed a protocol for seashore paspalum with immature inflorescence as explants and found 2,4-D $\left(3.0 \mathrm{mg} \cdot \mathrm{L}^{-1}\right)$ alone was effective in callus induction with the highest callus induction percentage of $58 \%$, whereas 6 -BA had no effects on callus induction and the combination of dicamba $\left(3 \mathrm{mg} \cdot \mathrm{L}^{-1}\right)$ and 6-BA $\left(1.0 \mathrm{mg} \cdot \mathrm{L}^{-1}\right)$ was highly effective for plant regeneration. Our study determined the optimal level of cytokinin and auxin analogs as well as another two supplements in the culture medium for callus induction, embryogenic callus formation, and plant regeneration for seashore paspalum using viable seeds as explants. This study demonstrated that our optimized protocol effectively improved callus induction, embryogenic callus formation, and plant regeneration for seashore paspalum, as discussed below.

In our study, the most effective culture medium resulting in the highest callus induction percentage from seeds $(66.88 \%)$ was supplemented with $2,4-\mathrm{D}$ at $3.0 \mathrm{mg} \cdot \mathrm{L}^{-1}$ and $\mathrm{CuSO}_{4}$ at
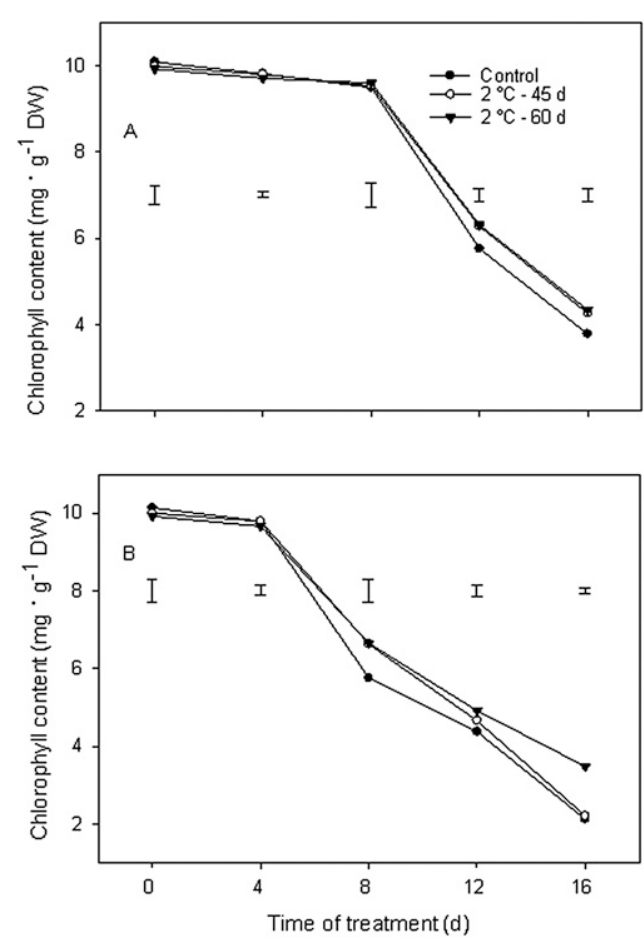

Fig. 6. Leaf chlorophyll content (Chl) in seashore paspalum 'Sea Spray' plants derived from cold-selected calli at $2{ }^{\circ} \mathrm{C}$ for 45 or $60 \mathrm{~d}$ in response to two growing temperatures (day/night): $15 / 10{ }^{\circ} \mathrm{C}(\mathbf{A})$ and $5 / 3{ }^{\circ} \mathrm{C}(\mathbf{B})$. Vertical bars represent the least significant difference values $(P \leq 0.05)$ for comparison between the control plants (non-cold-selected) and the regenerated plants from callus at $2{ }^{\circ} \mathrm{C}$ for 45 or $60 \mathrm{~d}$ at a given day of low growing temperature treatment

$10.0 \mathrm{mg} \cdot \mathrm{L}^{-1}$ and the optimal culture medium composition for the highest percentage of embryogenic callus formation (55.94\%) included 2,4-D at $3.0 \mathrm{mg} \cdot \mathrm{L}^{-1}, \mathrm{CuSO}_{4}$ at $15 \mathrm{mg} \cdot \mathrm{L}^{-1}$, and $\mathrm{AHC}$ at $1.0 \mathrm{~g} \cdot \mathrm{L}^{-1}$, whereas $6-\mathrm{BA}$ at $1.0 \mathrm{mg} \cdot \mathrm{L}^{-1}$ was inhibitory for callus formation and all levels of 6-BA inhibited embryogenic callus formation. The addition of $\mathrm{CuSO}_{4}$ and AHC not only enhanced callus induction and formation, but also improved callus quality resulting in a lesser degree of browning. The $2,4-\mathrm{D}$ at concentrations up to $8 \mathrm{mg} \cdot \mathrm{L}^{-1}$ was effective for callus induction of perennial ryegrass but higher concentrations were not conducive to the formation, differentiation, and regeneration of embryogenic callus (Zeng et al., 2009). Our results demonstrated that high concentrations $\left(0.1 \mathrm{mg} \cdot \mathrm{L}^{-1}\right)$ of 6 -BA were inhibitory to callus induction from seeds of seashore paspalum. Zeng et al. (2009) also reported high concentrations of 6-BA $\left(0.1\right.$ to $\left.0.5 \mathrm{mg} \cdot \mathrm{L}^{-1}\right)$ inhibited callus formation from seeds in perennial ryegrass. The combination of 2,4-D with a lower concentration of cytokinins in the callus induction medium resulted in the formation of very compact embryogenic callus structure in zoysiagrass [Zoysia japonica (Chai et al., 2011)]. However, in our study, the embryogenic structure that could be regenerative for plant formation was not observed in the medium supplemented with 6-BA. These results suggested that auxin was essential for callus induction and embryogenic callus formation, whereas low concentrations of 6-BA were not conducive but high concentrations were inhibitory to callus induction, and 6-BA at all concentrations was inhibitory to embryogenic callus formation in seashore paspalum. Our results were consistent with previous research 
that the requirement of cytokinins in callus induction and somatic embryogenesis may be dependent on plant species and the type of explants.

For plant regeneration in seashore paspalum, the combination of a high concentration of $6-\mathrm{BA}\left(8.0 \mathrm{mg} \cdot \mathrm{L}^{-1}\right), \mathrm{KT}\left(0.2 \mathrm{mg} \cdot \mathrm{L}^{-1}\right)$, and NAA $\left(0.5 \mathrm{mg} \cdot \mathrm{L}^{-1}\right)$ was most effective in promoting the regeneration rate. Improved regeneration rates with low levels of cytokinins and auxins were reported in several other turfgrass species, including hybrid bermudagrass [Cynodon dactylon $\times$ Cynodon transvaalensis (Chaudhury and $\mathrm{Qu}, 2000)]$, kentucky bluegrass (Griffin and Dibble, 1995), and creeping bentgrass [Agrostis stolonifera (Zhong et al., 1991)]. The present study optimized the tissue culture system for seashore paspalum using seeds as explants, which allowed establishment of highly regenerable callus and generated healthy plants, and can be used in somaclonal variation selection and genetic transformation in seashore paspalum.

As discussed in the introduction, in vitro selection for somaclonal variation in stress tolerance has been proven effective in creating genetic variation in stress tolerance. Most previous studies in crop species and turfgrass species have screened for natural somaclonal variations with callus formed under optimal environmental conditions. Lu et al. (2006) generated hybrid bermudagrass variants with improved drought tolerance through selection of natural somacloanal variations. The improved drought tolerance in the selected variant lines was further reflected by lower levels of leaf EL and oxidative stress compared with that of the parental line (Lu et al., 2009). Through selection from natural somaclonal variations, Li et al. (2010) obtained some variants of st. augustinegrass (Stenotaphrum secundatum) with improved freezing tolerance. Few studies have examined stress-induced somaclonal variations (Kendall et al., 1990), and no previous research has dealt with selection of cold-tolerant turfgrass germplasm by using in vitro cold selection. In this study, plants of seashore paspalum derived from cold-selected callus from individual seeds exhibited significant improvement in cold tolerance, as manifested by higher TQ, chlorophyll content, lower EL, and MDA content compared with the control plants. The physiological data indicated that the improved cold tolerance through in vitro selection was associated with the maintenance of chlorophyll accumulation and cell membrane stability as well as the suppression of membrane lipid peroxidation. The molecular characterization and heritability of the variations will be further evaluated in future studies. In addition, the cold-selected variants will be tested for use in field breeding conditions. To our knowledge, this is the first research effort that optimized the protocol for in vitro culture of seashore paspalum using seeds as explants and attests to the effectiveness of in vitro cold-selected selection for improving cold tolerance in a warm-season turfgrass species. This approach could be applicable for generating stress-tolerant germplasm for turfgrass tolerance to other abiotic stresses and the cold-tolerant variants may be used for exploring molecular and genetic traits associated with the improved cold tolerance through in vitro culture selection.

\section{Literature Cited}

Arnon, D. 1949. Copper enzymes in isolated chloroplasts. Polyphenoloxidase in Beta vulgaris. Plant Physiol. 24:1-15.

Bai, Y. and R. Qu. 2001. Factors influencing tissue culture responses of mature seeds and immature embryos in turf-type tall fescue. Plant Breed. 120:239-242.
Barampuram, S., B.Y. Chung, S.S. Lee, B.C. An, E.M. Lee, and J.-Y. Cho. 2009. Development of an embryogenic callus induction method for centipede grass (Eremochloa ophiuroides Munro) and subsequent plant regeneration. In Vitro Cell. Dev. Biol. Plant 45:155-161.

Beard, J.B. 1973. Turfgrass science and culture. Prentice-Hall, Englewood Cliffs, NJ.

Bertin, P. and J. Bouharmont. 1997. Use of somaclonal variation and in vitro selection for chilling tolerance improvement in rice. Euphytica 96:135-142.

Blum, A. and A. Ebercon. 1981. Cell membrane stability as a measure of drought and heat tolerance in wheat. Crop Sci. 21:43-47.

Cardona, C.A. and R.N. Duncan. 1997. Callus induction and high efficiency plant regeneration via somaclonal embryogenesis in paspalum. Crop Sci. 37:1297-1302.

Chai, M., Y. Jia, S. Chen, Z. Gao, H. Wang, L. Liu, P. Wang, and D. Hou. 2011. Callus induction, plant regeneration, and long-term maintenance of embryogenic cultures in Zoysia matrella [L.] Merr. Plant Cell Tissue Organ Cult. 104:187-192.

Chaudhury, A. and R. Qu. 2000. Somatic embryogenesis and plant regeneration of turf-type bermudagrass: Effect of 6-benzyladenine in callus induction medium. Plant Cell Tissue Organ Cult. 60:113120.

Dahleen, L.S. 1995. Improved plant regeneration from barley callus cultures by increased copper levels. Plant Cell Tissue Organ Cult. 43:267-269.

Dhindsa, R.S. and W. Matowe. 1981. Drought tolerance in two mosses: Correlated with enzymatic defense against lipid peroxidation. J. Expt. Bot. 32:79-91.

Duncan, R.R. and R.N. Carrow. 1999. Seashore paspalum-The environmental grass. Wiley, Hoboken, NJ.

Griffin, J.D. and M.S. Dibble. 1995. High-frequency plant regeneration from seed-derived callus cultures of kentucky bluegrass (Poa pratensis L.). Plant Cell Rep. 14:721-724.

Ha, C.D., P.G. Lemaux, and M.J. Cho. 2001. Stable transformation of a recalcitrant kentucky bluegrass (Poa pratensis L.) cultivar using mature seed-derived highly regenerative tissues. In Vitro Cell. Dev. Biol. Plant 37:6-11.

Health, R.L. and L. Packer. 1968. Photoperoxidation in isolated chloroplasts. I. Kinetics and stoichiometry of fatty acid peroxidation. Arch. Biochem. Biophys. 125:189-198.

Karp, A. 1995. Somaclonal variation as a tool for crop improvement. Euphytica 85:295-302.

Kendall, E.J., J.A. Qureshi, K.K. Kartha, N. Leung, N. Chevrier, K. Caswell, and T.H.H. Chen. 1990. Regeneration of freezingtolerant spring wheat (Triticum aestivum L.) plants from cryoselected callus. Plant Physiol. 94:1756-1762.

Lazar, M.D., T.H.H. Chen, L.V. Gusta, and K.K. Kartha. 1988. Somaclonal variation for freezing tolerance in a population derived from norstar winter wheat. Theor. Appl. Genet. 75:480-484.

Li, R., R. Qu, A.H. Bruneau, and D.P. Livingston. 2010. Selection for freezing tolerance in St. Augustinegrass through somaclonal variation and germplasm evaluation. Plant Breed. 129:417-421.

Lu, S., C. Chen, Z. Wang, Z. Guo, and H. Li. 2009. Physiological responses of somaclonal variants of triploid bermudagrass (Cynodon transvaalensis $\times$ Cynodon dactylon) to drought stress. Plant Cell Rep. 28:517-526.

Lu, S., Z. Wang, X. Peng, Z. Guo, G. Zhang, and L. Han. 2006. An efficient callus suspension culture system for triploid bermudagrass (Cynodon transvaalensis $\times C$. dactylon) and somaclonal variations. Plant Cell Tissue Organ Cult. 87:77-84.

Murashige, T. and F. Skoog. 1962. A revised medium for rapid growth and bio-assays with tobacco tissue cultures. Physiol. Plant. 15:473497.

Neibaur, I., M. Gallo, and F. Altpeter. 2008. The effect of auxin type and cytokinin concentration on callus induction and plant regeneration frequency from immature inflorescence segments of seashore paspalum (Paspalum vaginatum Swartz). In Vitro Cell. Dev. Biol. Plant 44:480-486. 
Olesen, A., M. Storgaard, S. Madsen, and S. Andersen. 1995. Somatic in vitro culture response of Lolium perenne L.: Genetic effects and correlations with anther culture. Euphytica 86:199-209.

Sahrawat, A.K. and S. Chand. 1999. Stimulatory effect of copper on plant regeneration in indica rice (Oryza sativa L.). J. Plant Physiol. 154:517-522.

Tahiliani, S. and S.L. Kothari. 2004. Increased copper content of the medium improves plant regeneration from immature embryo derived callus of wheat (Triticum aestivum). J. Plant Biochem. Biotechnol. $13: 85-88$.
Van Ark, H.F., M.A.C.M. Zaal, J. Creemers-Molenaar, and P. Van der Valk. 1991. Improvement of the tissue culture response of seedderived callus cultures of Poa pratensis L.: Effect of gelling agent and abscisic acid. Plant Cell Tissue Organ Cult. 27:275-280.

Zeng, S., J. Bian, Z. Fang, D. Zhang, and X. Zhou. 2009. Callus induction and plant regneration from mature seeds of perennial ryegrass. Agr. Sci. Technol. 10:33-36.

Zhong, H., C. Srinivasan, and M.B. Sticklen. 1991. Plant regeneration via somatic embryogenesis in creeping bentgrass (Agrostis palustris Huds.). Plant Cell Rpt. 10:453-456. 